\title{
Prevention of Student Youth's Victim Behavior
}

\author{
Albina R. Drozdikova-Zaripova ${ }^{1}$, Nadezhda Y. Kostyunina ${ }^{1} \&$ Natalia N. Kalatskaya ${ }^{1}$ \\ ${ }^{1}$ Kazan (Volga region) Federal University, Kazan, Russia \\ Correspondence: Albina R. Drozdikova-Zaripova, Kazan (Volga region) Federal University, Kremlyovskaya \\ Street 18, Kazan, 420008, Russia.
}

Received: December 29, 2014

Accepted: January 22, 2015 Online Published: February 11, 2015

doi: $10.5539 /$ res.v7n4p88

URL: http://dx.doi.org/10.5539/res.v7n4p88

\begin{abstract}
New times put forward new tasks for teachers, psychologists, social workers. Prevention of student youth's victim behavior is determined by social and practical importance of society democratization and humanization; by the necessity to develop physically and spiritually healthy, actively creating and socially adapted personality, by the increased demand for victimologic prevention and correction.

The article substantiates the essence and motives of student youth's victim behavior; it also reveals specific characteristics of student age: emotional immaturity, insufficient ability to control own behavior and other factors that increase the risk of becoming "a victim" due to adverse conditions of socialization.

The research has resulted in defining pedagogical conditions aimed to prevent victim behavior: diagnostics to identify victim behavior among students; development and introduction of comprehensive prevention program "Life out of danger!". The conducted research allowed to draw a conclusion that the approved program due to included various forms and methods offers an effective way to prevent student youth's victim behavior.
\end{abstract}

Keywords: personality victimization, victim behavior, deviant behavior of the individual, students, prevention

\section{Introduction}

\subsection{Actualization of the Problem}

The relevance of the problem concerning student youth's victim behavior is determined by an aggravated tendency to the increase of the designated contingent among young people notorious for deviant behavior and becoming victims of crimes. We can note that negative tendencies provoking personality's victim behavior and quite often leading to dangerous critical situations in life have increased. There are not enough experimental studies of personality's victim behavior prevention (in particular among student youth) in Russian social pedagogics and psychology. There are only few works studying psychological features of children and teenagers on the basis of forensic-psychiatric material (Morozova, 2003; Polubinsky, 1980; Franc, 1977). However, the necessity for such researches is getting more and more urgent in connection with practical prevention (Sinelnikov \& Sereda, 2002). Such issues as the genesis of victim behavior, system of factors determining its emergence, features characteristic for the manifestation of these patterns in students' behavior have not been studied enough so far. Besides there is no complex system of preventive actions aimed to prevent student youth's victim behavior. Therefore, the issue concerning the prevention of student youth's victim behavior is one of the leading areas of pedagogue-psychologist's work in an educational institution.

\subsection{Status of the Problem}

The term "victim behavior" appeared within criminal victimology. Now "victimhood" and "victim behavior" have become the subject of close attention of social psychology, psychopathology, social pedagogics.

The analysis of this issue in psychological and pedagogical literature and practice allowed to reveal a number of contradictions:

1) Between the ambiguous impact of various circumstances which put a young man in a difficult situation and the absence of knowledge and abilities to overcome difficult life situations.

2) Between pedagogues', psychologists' intention to solve the problem of victimhood and undeveloped contents, forms, methods and means aimed to provide effective prevention of victimogenic situations.

Having studied the concepts of foreign and Russian scientists, such as Zagvyazinsky (2012), Kudryavtsev (2007), 
Selivanov (2012), Franc (1977), Holyst (1984), Schneider (1994), etc., we consider victim behavior as careless, immoral, and provocative behavior. We will consider student's personality victim if it has such features as excessive trustfulness, rashness, increased irascibility and irritability, aggression, and if their behavior is characterized by the tendency to adventurous, impudent, violent and impulsive acts.

As a result of the research there have been singled out the most effective constraining barriers of victim behavior, they are as follows: individual personality qualities, deep understanding of life value, confidence in own forces, communicativeness, openness to experience and feelings of other people, prevention of victim behavior in all institutes of the society; effective work of social teachers and psychologists; there has been carried out experimental work and have been developed forming actions aimed to prevent student youth's victim behavior.

\subsection{Purpose and Hypothesis of the Research}

The research objective is to substantiate theoretically and verify experimentally the contents, set of forms and methods providing effective prevention of student youth's victim behavior.

The analysis of theoretical works and practical activities of the studied problem showed that issues connected with student youth's victim behavior prevention present an insufficiently researched area of scientific knowledge and practical activities that as a result allowed to formulate a hypothesis of the research of this problem: the efficiency of student youth's victim behavior prevention process may be increased if:

- To be guided by essential characteristics of such concepts as "victim behavior", "victimhood", "victim personality";

- To consider characteristic features of student youth's victim behavior manifestation;

- To study forms and methods of victim behavior prevention;

- To develop and implement the program of victim behavior prevention "Life without danger!", which contains effective forms and methods aimed to decrease the level of student youth's victimhood.

\section{Materials and Methods}

\subsection{Tasks of the Research}

In compliance with the hypothesis, proceeding from understanding of the issue, the goals and object, the subject of the research the following tasks have been created: 1) on the basis of psychological and pedagogical literature analysis to reveal the essence and content of such concepts as "victimhood", "victim personality", "victim risks"; 2) to study characteristic features of student youth's victim behavior manifestation; 3 ) to develop the content of the program which includes various forms and methods of student youth's victim behavior prevention; 4) to verify in pilot-experimental work the efficiency of the elaborated program "Life without danger!" the aim of which is to decrease the level of student youth's victim behavior.

\subsection{Methods of Research}

According to the goal and research tasks the following methods of research were applied:

1) Theoretical: the study and analysis of psychological, pedagogical and methodical literature, of legislative, instructive-methodological, working materials and materials of procedural character concerning the research problem; studying and generalization of innovative social pedagogical experience; the analysis and synthesis;

2) Empirical: observation, questioning, testing, experiment;

3) Methods of high-quality interpretation and data processing (parametrical Student's t-test $>1$ for dependent samples).

\subsection{Diagnostic Tools}

Detection of students' tendency to victim behavior was carried out with the help of the following techniques:

1) The questionnaire "What do we know about victimhood?" allowed to study students' awareness about the essence, motives, ways of victim behavior prevention;

2) The technique "Tendency to victim behavior" by Andronnikova (2005) was carried out to determine the level of potential and realized victimhood as a person's personality trait. The research technique of potential victim behavior intended to diagnose some aspects of teenagers' and youth's behavior connected with internal potential victimhood realization and the definition of the leading type of personality's victim activity.

3) The diagnostics "Locus of control". The test-questionnaire by Rotter (1954) in Panteleev and Stolin's adaptation (1988) was used to find out a locus of control of students from the "risk group". Locus of control is 
understood by the authors as a personality quality that characterizes person's tendency to attribute responsibility for activity results to external forces (external, i.e. external locus of control) or to own abilities and efforts (internal, internal locus of control).

The hypothesis reliability was confirmed by statistical processing with the help of parametrical Student's t-test for dependent samples. Comparing the results obtained at the stating and at the control stage of the experiment we found out how effective applied victimhood prevention methods were, and to what degree they reduced victim risks.

\subsection{Arrangement of Research}

The research was conducted in three stages:

At the first search and theoretical stage the analysis of the issue in pedagogical and psychological literature was conducted; scientific categories and research basis were defined; pilot-experimental research techniques were selected.

Students of Kazan social and humanitarian technical college (123 persons-young men and girls) aged between 17-18 years took part in the experiment. After the pilot research, we selected the sample "risk group" that made $14 \%$.

At the second pilot-experimental stage the research hypothesis was verified; forms and methods of pedagogical interaction with student youth to decrease the level of victim behavior were approved.

At the third (summarizing) stage the systematization and processing of research results was carried out; the theoretical and experimental conclusions were developed.

\subsection{The Course and Description of the Experiment}

1) The stating stage original values definition of studied indicators. The pilot research allowed to select students of the "risk group" out of 123 young men and girls. Further we will describe the results obtained after diagnostic techniques application. The results of questioning revealed such characteristic features of respondents as excessive trustfulness, rashness, increased irascibility and irritability, aggression; in behavior there was singled out the tendency to adventurous, impudent, violent and impulsive acts.

The research of tendency to victim behavior (Andronnikova, 2005) showed that young men and girls of the "risk group" are inclined to get into unpleasant and life- and health-threatening situations as a result of displayed aggression in the form of attack or any other provocative behavior (insult, slander, mockery). An intention to create or provoke a conflict situation is characteristic for them. Their behavior can be the realization of typical for them an antisocial personality orientation. Aggression is demonstrated towards certain persons and in certain situations (selectively). There is a tendency to antisocial behavior, violation of social norms, rules and ethical values which are often neglected by the subject. Such people easily give in to emotions, especially of negative character, and they express them brightly, they are dominant, impatient, hot-tempered. More than a half of respondents are characterized by increased anxiousness, suspiciousness, passivity, indifference to events that happen round them, they act according to the principle "it is none of my business"; this can be caused by the fact that they either take offense at the outside world, or it can be developed as a result of feeling that they are not understood, that they are isolated from the world, that they experience the lack of social support and inclusiveness in the society.

The results of the test-questionnaire "Locus of control" (in S. R. Panteleev and V. V. Stolin's adaptation) were the following. $78 \%$ of respondents in the "risk group" have an external locus of control that testifies to the fact that these students are inclined as a rule to blame surrounding people or some circumstances for all their failures, mistakes and faults. They consider themselves always right in conflict situations, they can easily escalate the situation, they are aggressive and do not admit their guilt even if they understand it. They are irritable, emotionally unstable, impulsive, inclined to emotional breakdowns.

On the basis of these results some forming actions have been developed.

2) The forming stage during which the comprehensive prevention program "Life out of danger!" was implemented.

At the social-pedagogical level, the system of victimologic prevention represents an arranged purposeful activity of psychologists and social teachers aimed to identify and eliminate various victimologic phenomena and processes in the sphere of social relations that cause victimization of the human personality as the potential victim of criminal encroachments of a specific individual or circumstances. 
The prevention program "Life out of danger!" was based on the practical experience of the Russian scientist Malkina-Pykh (2006); the program allowed to realize such methods and forms as modeling of "dangerous situations", playing of conflict situations, exercises, discussions, music therapy, play therapy. These forms and methods were aimed at the prevention of illegal actions (for example, not to open the door for strangers, not to enter the entrance hall and elevator with them, not to get acquainted on the street, not to give in to persuasion, etc.), at the development and formation of skills and abilities that promote social adaptation; at the elaboration of behavior strategies in threatening situations. The forming actions allowed to develop constructive ways of students' safe behavior and to develop such traits of character as the absence of conflictness, "non-aggressiveness", confidence, determination.

3) At the control stage of the experiment there were analyzed the results obtained before and after the forming experiment stage, there was carried out the statistical data processing with the view to confirm the hypothesis (according to Student t-test for dependent samples). In compliance with the technique "Tendency to victim behavior" by O. O. Andronnikova $t_{\text {emp }}$. is in the zone of insignificance on scales "social importance of answers" $\left(t_{\text {emp }}=1,62\right)$, tendency to self-damaging and self-destructive behavior" ( $\left.t_{\text {emp }}=1,2\right)$, where $t_{\text {emp }}<t_{c r}$ in the zone of significance on the following scales: "aggressive behavior" $\left(\mathrm{t}_{\mathrm{emp}}=3,5\right)$, "tendency to hyper-social behavior" ( $\mathrm{t}_{\mathrm{emp}}$ $=2,84)$, "tendency to dependent and helpless behavior" ( $\left.\mathrm{t}_{\mathrm{emp}}=2,65\right)$, "tendency to uncritical behavior" $\left(\mathrm{t}_{\mathrm{emp}}=2,9\right)$, "realized victimhood" $\left(t_{\text {emp }}=3,65\right)$, where $t_{\text {emp }}>t_{\text {cr }}$ respectively.

\section{Results}

Comparing results obtained before and after forming actions it is possible to say that the hypothesis put forward by us was confirmed partially, however, it is worth noticing that on the scale "realized victimhood", we placed emphasis on, the results were effective, the number of students in the "risk group" decreased by $25 \%$.

Thus, it is possible to draw a conclusion that the program of student youth's victim behavior prevention "Life out of danger!" contains effective forms and methods aimed to decrease victimhood and it can be used by teachers, psychologists, social workers in their professional activity to prevent student youth's victim behavior.

However during the program implementation we failed to solve completely a number of problems, such as absence from lessons, addictions to bad habits, isolation and unsociability, increased aggression. There may be singled out the following reasons:

Firstly, our program of student youth's victim behavior prevention did not work specifically in such directions as:

a) Prevention of addictions, however in the course of forming actions we touched upon such topics as healthy lifestyle and prevention of self-destructive behavior. Many students admitted their addictions and desire to get rid of them.

b) Development of communicative skills. Unsociable reserved students demand more attentive attitude towards themselves as difficulties arise when they have to express their thoughts and feelings in the group.

c) Correction of aggressive behavior. Most students in the "risk group" tend to display aggressive manifestations. Inadequate perception of criticism, unreasonable flashes of rage were demonstrated by these students rather often, however we managed to control their negative emotions during lessons.

Secondly, the program of student youth's victim behavior prevention was being realized in a technical college within 5 months after lessons. We think that this time is not enough.

Thirdly, the prevention can be effective in case if various departments and experts reveal their mutual interest and act consistently. In our work the prevention of victim behavior was carried out only with students, their parents did not participate in the experiment. Besides, the administration of the technical college did not provide students' medical records therefore we did not consider the contingent according to such a criterion as health. These issues require more accurate, planned and large-scale work in the activity of an educational psychologist in an educational institution.

\section{Conclusion}

Thus, it is possible to draw a conclusion that the program of student youth's victim behavior prevention "Life out of danger!" contains effective forms and methods aimed to decrease victimhood and it can be used by teachers, psychologists, social workers in their professional activity to prevent student youth's victim behavior. Victim behavior prevention is a nation-wide task, and it may be successfully resolved due to joint coordinated efforts of doctors, teachers, sociologists, psychologists, and a wide network of state and public organizations. 


\section{Acknowledgment}

The work is performed according to the Russian Government Program of Competitive Growth of Kazan Federal University

\section{References}

Andronnikova, O. O. (2005). Psychological factors of victim behavior of adolescents (Doctoral dissertation). Novosibirsk: NSPU.

Frank, L. V. (1977). Victims of crime and issues of Soviet victimology. Dushanbe: Irfon.

Holyst, B. (1984). The factors forming victimhood: Issues of fight against crime (Vol. 41, pp. 73-74). Moscow: Yuridicheskaya literatura.

Kudryavtsev, V. N. (2007). General theory of crimes qualification. Moscow: Yurist.

Malkina-Pykh, I. G. (2006). Psychology of victim's behavior. Moscow: EKSMO.

Morozova, N. B. (2003). Mental disorders and their role in children's and teenagers'victim behavior. Moscow: Prosveschenie.

Panteleev, S. R., \& Stolin, V. V. (1988). Test-questionnaire of subjective localization control. In J. Rotter (Ed.), Scale modification IE. Moscow: Moscow State University.

Polubinsky, V. I. (1980). Victimologic aspects in prevention of crimes. Moscow: Academiya MVD SSSR.

Rotter, J. B. (1954). Social learning and clinical psychology. NY: Prentice-Hall. http://dx.doi.org/10.1037/10788-000

Schneider, G. J. (1984). Criminology. Moscow: Progress-Univers.

Sinelnikov, A., \& Sereda, N. (2001). Safety of teenagers and healthy relationships, Model program of early violence prevention. Moscow: Anna.

Zagvyazinsky, V. I., \& Selivanov, O. A. (2012). Social pedagogics. Moscow: Publishing house of Yurait.

\section{Copyrights}

Copyright for this article is retained by the author(s), with first publication rights granted to the journal. This is an open-access article distributed under the terms and conditions of the Creative Commons Attribution license (http://creativecommons.org/licenses/by/3.0/). 